\title{
Feed Resource Availability and their Nutrient Contribution for livestock Evaluated Using Feed Assessment Tool (FEAST) in Burie Zuria District, North Western Ethiopia
}

\author{
Getahun Belay ${ }^{1}$ and Tegene Negesse ${ }^{2 *}$ \\ ${ }^{1}$ Department of Animal Science, Alage ATVET College, Ethiopia \\ ${ }^{2}$ School of Animal and Range Sciences, Hawassa University, Ethiopia
}

Submission: July 04, 2018, Published: August 21, 2018

"Corresponding author: Tegene Negesse, Hawassa University, College Agriculture, School of Animal and Range Sciences, P. 0. Box, 05, Hawassa, Ethiopia, Tel: +251916827711; Email: tegenengss38@gmail.com

\begin{abstract}
Constraints of livestock production, major livestock feed resources and their nutrient contribution (\% of respondents) and intervention options in three agro-ecologies of Burie Zuria district, north western Ethiopia, were assessed from data collected between January 2017 and February 2018. Agro-ecologies, kebeles and households (HHs) were selected using multi-stage sampling techniques. A single-visit multi subject formal survey was conducted. The district was stratified in to high, mid and low altitudes and data were collected from February to April 2017 on 90, 30 and $30 \mathrm{HHs}$, respectively using focus group discussion, individual interview, key informant interview, secondary sources and personal observation. Feed assessment tool (FEAST version 2.21), SPSS version 20.0 and general linear model procedure were used to analyze data. Feed shortage, limited knowledge of farmers in livestock production, poor genetic potential of indigenous cattle breeds, disease and land shortage were the main constraints affecting livestock production in all agro-ecologies in decreasing order of importance. Dry matter (DM) contribution of purchased feeds is lower but of crop residues higher than that of other feed resources. DM contribution of purchased feed in high altitude $(11.22 \pm 1.4)$ is higher $(\mathrm{p}<0.01)$ than in mid $(2.46 \pm 0.85)$ and low altitudes $(7.45 \pm 1.48)$ and that of crop residues was higher in low and mid altitude $(\mathrm{p}<0.01)$ than in high altitude. Highest $(\mathrm{p}<0.001)$ crude protein (CP) contribution was from crop residues in low $(49.75 \pm 3.03)$ and mid altitudes $(42.33 \pm 1.75)$ than in high altitude $(28.47 \pm 3.03)$ and lowest was from purchased feeds with highest $\mathrm{CP}$ contribution in high $(10.78 \pm 0.75, \mathrm{p}<0.001)$ than in mid $(2.44 \pm 0.43)$ and low altitudes $(4.93 \pm 0.75)$. Highest $(\mathrm{p}<0.001)$ metabolisable energy $(\mathrm{ME})$ contribution was from crop residues in low (52.91 \pm 1.23$)$ and mid altitudes $(51.12 \pm 0.71)$ than in high altitude $(31.67 \pm 1.23)$ and lowest was found from purchased feeds with highest $(\mathrm{P}<0.001) \mathrm{ME}$ in high altitude $(11.55 \pm 0.88)$ than in mid $(2.15 \pm 0.46)$ and low altitudes $(6.78 \pm 0.88)$. In conclusion, the main feed resource is crop residue which is of low nutritional quality. Chemical and biological treatments of crop residues and concentrate supplementation and training farmers on feeding and grazing management would improve nutritional value total diet.
\end{abstract}

Keywords: Agro-ecology; Crude protein; Dry matter; Metabolisable energy

Abbreviations: FEAST: Feed assessment tool; CP: Crude Protein; HHs: Households; DM: Dry matter; ME: Metabolisable Energy; SPSS: Statistical Package for Social Science; LSD: Least Significant Difference

\section{Introduction}

Livestock feed resources available in the study area are natural pasture, crop residues, improved forage, hay, industrial by products [1]. In Ethiopia natural pasture is the primary feed resource throughout the wet season while crop residues play a substantial role during dry season [2]. The current report revealed that $54.59,31.06,6.81,1.53,0.31$ and $5.11 \%$ of the total livestock feed supply of the country is derived from natural pasture, crop residues, hay, agro-industrial by-products, improved forage and other types of feeds, respectively [1]. Natural pasture accounts about $25 \%$ of total land mass of the country [3]. However, its productivity in most parts of Ethiopia is extremely low [3] due to seasonal fluctuation of rainfall and poor grazing land management and conversion of grazing land in to crop lands as a result of increased human population $[4,5]$.

The total annual production of crop residues at global and national level is estimated to be about 1.14 billion [6] and 30 million [7] tons of DM, respectively of which $70 \%$ is utilized as livestock feed. Moreover, crop residues are providing a considerable quantity of dry season feed in most farming areas of the country [8-11], and contributed up to $30-80 \%$ of the total feed DM available for animals in the highlands of Ethiopia [12]. However, crop residues are fibrous by products and their feeding values are limited by their poor voluntary intake and digestibility and low nitrogen, energy, mineral and vitamin contents [13]. 
Feed shortage has remained to be the most limiting factor of livestock production in the highlands of Ethiopia [14]. The most critical periods are from February to May, when all feed resources are virtually depleted, and conservation of crop residues is inadequate in the highland of Ethiopia [15]. Crop residues are nonetheless of low nutritive value and cannot bear sensible animal production. Livestock feed problem is more intense in the highlands of the country where more than $75 \%$ of both the human and livestock population are concentrated. As a result, livestock productivity is generally lower than the potential [16]. On the other hand, availability and utilization of different feed resources varies depending up on agro-ecology, livestock production system and seasons of the year. Hence, assessment of feed resources helps to guide the development of effective intervention strategies to improve quality of feeds, feed use efficiency and livestock productivity. Thus this study was carried out to evaluate availability of potential feed resources and their utilization by livestock in Burie zuria district of north western Ethiopia.

\section{Materials and Methods}

\section{Main features of the study area}

The survey was conducted during January 2017- February 2018 in Burie Zuria district. The district is located $400 \mathrm{~km}$ North West of Addis Ababa and $148 \mathrm{~km}$ South West of the Regional State capital, Bahir Dar, North Western highlands of Ethiopia at a coordinate of $10^{\circ} 15^{\prime} \mathrm{N}$ and $10^{\circ} 42^{\prime} 29^{\prime \prime} \mathrm{N}$ latitude and $36^{\circ} 52^{\prime} 1^{\prime \prime} \mathrm{E}$ and $37^{\circ} 7^{\prime} 9^{\prime \prime} \mathrm{E}$ longitude with an altitude range of 700 to $2350 \mathrm{~m}$.a.s.l [17]. Currently, the district had 18 kebeles [18] with a total human population of about 104,784 and 13,940 male headed, 1,988 female headed and 15,928 total HHs [17].

According to Burie Zuria District office of Agriculture [18], the total area of the district is 58,795 ha, out of which $52.2 \%$ and $5.2 \%$ is crop lands and grazing areas, respectively. The topography of the district is dominated by plain type (76\%) and the remaining constitute mountain (10\%), undulating $(7 \%)$ and gorge $(\%)$. The three agro-ecological zones found in the district are mid (82\%), low $(10 \%)$ and high altitudes (8\%). Long term minimum, maximum and mean temperatures are 14,24 and $19{ }^{\circ} \mathrm{C}$, respectively. The rainfall pattern is uni-modal (May to September) and the minimum, maximum and mean annual rainfall is 1000, 1500 and $1250 \mathrm{~mm}$, respectively. The livelihood of most of the population is agriculture. The major crops grown in the district are maize, finger millet, teff, wheat, barley, potato, pepper, onion, field pea and fava bean. The types of livestock reared in the district include cattle, sheep, goat, equine and chicken [17]. The total population of cattle, sheep, goats, equines and chickens were estimated to be about $98807,31120,11300,9191$ and 66705, respectively [18].

\section{Sample size determination and sampling techniques}

The number of HHs sampled in the study area was determined by $\mathrm{N}=0.25 / \mathrm{SE} 2$, where $\mathrm{N}=$ number of sampled HHs, $\mathrm{SE}=$ standard error [19]. Considering, SE of $4.09 \%$ at a precision level of $5 \%$ and $95 \%$ confidence interval. Accordingly, $150 \mathrm{HHs}$ were selected. Multistage purposive sampling technique was used for the survey.
A single-visit multi subject formal survey method was used for the study [20]. The district was chosen based on the information of Zone Agriculture Office that there is relatively large number of animals. A reconnaissance survey was carried out to have an understanding of the study area and to select representative agroecologies before proceeding to formal survey. The district was stratified into high (greater than 2,300 meters above sea level), mid (1,500-2,300 meters above sea level) and low land (less than 1,500 meters above sea level) based on the Ethiopian agroecological classification [21] and secondary data obtained from the district [17]. Kebele is the lowest government administrative units below district. Accordingly, Zalema, Wadera Gendeba and Tiya Tiya (from mid altitude), Fetam Sentom (from low altitude) and Jib Gedele (from high altitude) kebeles were purposively included in the survey out of the total 12, 3 and 3 kebeles, respectively, in consultation with the districts' livestock expert based on the size of agro-ecological zones and the potential of livestock resources. Then two villages were purposively selected from each of the five kebeles with the help of kebele administrators and development agents.

Prior to selecting respondents, a brainstorming session was prearranged with the district livestock experts, kebele administrators and development agents on the objective of the study, the permanent benefits of the farming community from the survey and the respondents selection criteria. Purposive sampling technique was used to select respondents. Development agents and kebele representatives of the chosen kebeles selected respondents based on land holding, wealth category (small, medium and large), HH headship (men and women HH head), age group (youth, middle age and elders), livestock holding and experience of keeping livestock.

The selection of respondents for focus group discussion was done purposively by key informants. The respondents included in the survey had at least two species of livestock and two years of experience in livestock production. In each village, $15 \mathrm{HH}$ heads (10 men and 5 women) for one group [22], were selected for focus group discussion, giving a total of 150 farmers in 10 villages. After the focus group discussion, according to FEAST's recommendations, 9 farmers were selected from each village (total of 90) for semi-structured questionnaire; then they were stratified into three wealth categories through stratified sampling techniques based on existing community standards [23], and were interviewed independently. The number of respondents per agroecology were designed to be proportional to total number of $\mathrm{HHs}$ in each agro-ecology for focus group discussion (30, 30 and 90) and for individual interview (18,18 and 54) from high, low and mid agro-ecologies, respectively.

\section{Data collection methods and tools}

Qualitative and quantitative investigation was carried out using FEAST developed by International Livestock Research Institute [24], which offers a systematic and rapid methodology to assess feed resources availability and utilization at a site level 
with a view to developing a site-specific intervention approach to improve and optimize feed supply and utilization through technical or organizational interventions and characterize the livestock production system. FEAST differs from conventional feed assessment approaches that focus on the feeds nutritive value and ways to improve it. FEAST encompasses focused group exercises which provide an indication of the production system with a particular emphasis on livestock feed resources and a simple and succinct quantitative questionnaire intended to be completed by professionals under the direction of FEAST facilitator. The tool was pretested on $5 \%$ of the sample size in a similar setting to evaluate appropriateness of the design, clarity and interpretation of the question by farmers, relevance of the questions and time taken for interview to make appropriate modification and corrections. The questionnaire was then amended, further refined and fully structured for the final interview.

During the survey, information was mainly gathered through focus group discussion and individual interview. The focus group discussion guide was designed to capture feed context/issues like labour availability, cash/credit availability and availability of input delivery, availability of land for fodder cultivation, rainfall patterns, utilization of livestock feeds and current problems affecting livestock production mainly related to feed resource availability and potential solutions to these problems. The individual interview questionnaire was designed to capture about on-farm feeding strategies and nutrient availability. In addition, key informant interview and discussion with district livestock experts to confirm information obtained from group discussions and individual interviews and field observations were made to assess the feed utilization. Three key informants were made from within participants selected from development agents, kebele officials and elderly people who have detailed information about the kebele.

Secondary data accessible in the district, zone and region agricultural offices were extensively used. Furthermore, secondary data collected from all possible relevant sources (published and unpublished documents) were reviewed to strengthen the information. Information from secondary sources were gathered by reviewing different literatures between February and April 2017.

\section{Evaluation of feed resources}

Individual interview of farmers aims at collecting quantitative information on feed resource availability and quality. Responses collected during individual interviews were used to calculate approximate average values on a per $\mathrm{HH}$ basis for key variables related to feeding such as; the composition of diet, availability of dry matter (DM), metabolisable energy (ME) and crude protein (CP) in the diet. Calculation of these variables was based on the quantities of purchased feed status by farmers and the level of onfarm crop residues and other feed resources production. Standard DM, ME and CP values for feed materials was obtained from FEAST Software Version 2.21 [25].

\section{Statistical analysis}

The collected data was managed and organized with MS-Excel and was analyzed using the updated FEAST software version 2.21 [25], and statistical package for social science (SPSS) version 20 [26], for further analysis with the procedure of general linear model. Means were compared using least significant difference (LSD), adopting the probability level of $5 \%$. In all univariate analyses, $p$-value $<0.05$ was considered as a cut-off point for statistical significance. The statistical model used for the assessment of feed resource availability and utilization:

$$
Y_{i j}=\mu+\alpha_{i}+e_{i j}
$$

Where:

$$
\begin{aligned}
& \mathrm{Y}_{\mathrm{ij}}=\text { the response of the; } j^{\text {th }} \text { HH in the } i^{\text {th }} \text { agro-ecologies } \\
& \mu=\text { overall mean } \\
& \alpha \mathrm{i}=\text { effect of } i^{\text {th }} \text { agro-ecologies }(\mathrm{i}=3) \\
& \mathrm{e}_{\mathrm{ij}}=\text { random error }
\end{aligned}
$$

\section{Results and Discussion}

\section{Land used for crop production}

The dominant crops grown in the area are maize, pepper, wheat, teff, barley, finger millet, field pea, fava bean, noug and potato (Table1). Land allocated for maize, wheat and finger millet was higher $(\mathrm{P}<0.001)$ in mid and low altitude than high altitude but, for barley it is the reverse. Land allocated for field pea was higher $(\mathrm{P}<0.01)$ in low altitude than mid altitude. Land allocated for noug and teff was higher $(\mathrm{p}<0.01)$ in mid and low altitude than high altitude but, for fava bean it was higher $(\mathrm{p}<0.05)$ in mid than high altitude. However, there is no significant difference in land allocation for the remaining crops among the three altitudes/ agro-ecologies. The overall land holding per $\mathrm{HH}$ in the current study was $1.8 \pm 0.12 \mathrm{ha}$. However, there is a significant difference in land holding per $\mathrm{HH}$ among agro-ecologies. The higher land

\begin{tabular}{|c|c|c|c|c|c|}
\hline \multirow{2}{*}{ Crops } & \multicolumn{3}{|c|}{ Agro-Ecology } & \multirow{2}{*}{ Overall $(\mathrm{N}=90)$} & \multirow{2}{*}{ SL } \\
\hline & Mid Altitude ( $\mathrm{N}=54$ ) & Low Altitude ( $\mathrm{N}=18)$ & High Altitude ( $\mathrm{N}=18)$ & & \\
\hline Maize & $0.57 \pm 0.04 \mathrm{~b}$ & $0.56 \pm 0.07 \mathrm{~b}$ & $0.20 \pm 0.09 \mathrm{a}$ & $0.44 \pm 0.04$ & $* * *$ \\
\hline Wheat & $0.49 \pm 0.03 c$ & $0.34 \pm 0.06 \mathrm{~b}$ & $0.23 \pm 0.06 \mathrm{a}$ & $0.36 \pm 0.03$ & $* * *$ \\
\hline Pepper & $0.52 \pm 0.07$ & $0.66 \pm 0.10$ & $0.21 \pm 0.25$ & $0.46 \pm 0.09$ & NS \\
\hline
\end{tabular}
holding of farmers in low altitudes might be due to expansion of farmland without restriction by clearing of forest and low population density of the area.

Table 1: Allocation of land (ha, Mean \pm SEM) for the production of different types of crops. 
Agricultural Research \& Technology: Open Access Journal

\begin{tabular}{|l|l|l|l|l|l|}
\hline Finger millet & $0.30 \pm 0.02 \mathrm{~b}$ & $0.33 \pm 0.07 \mathrm{~b}$ & $0.24 \pm 0.03 \mathrm{a}$ & $0.29 \pm 0.03$ & $* * *$ \\
\hline Teff & $0.30 \pm 0.03 \mathrm{ab}$ & $0.44 \pm 0.05 \mathrm{~b}$ & $0.21 \pm 0.07 \mathrm{a}$ & $0.32 \pm 0.03$ & $*$ \\
\hline Barley & $0.27 \pm 0.02 \mathrm{~b}$ & $0.17 \pm 0.02 \mathrm{a}$ & $0.50 \pm 0.06 \mathrm{c}$ & $0.31 \pm 0.02$ & $* * *$ \\
\hline Field pea & $0.23 \pm 0.06 \mathrm{a}$ & $0.38 \pm 0.04 \mathrm{~b}$ & - & $0.31 \pm 0.04$ & $* *$ \\
\hline Noug & $0.28 \pm 0.028 \mathrm{~b}$ & $0.31 \pm 0.03 \mathrm{~b}$ & $0.22 \pm 0.05 \mathrm{a}$ & $0.27 \pm 0.02$ & $* *$ \\
\hline Faber bean & $0.28 \pm 0.02 \mathrm{~b}$ & - & $0.12 \pm 0.02 \mathrm{a}$ & $0.2 \pm 0.017$ & $*$ \\
\hline Potato & - & - & $0.17 \pm 0.04$ & $0.17 \pm 0.04$ & NS \\
\hline Total & $2.03 \pm 0.14 \mathrm{~b}$ & $2.5 \pm 0.24 \mathrm{~b}$ & $0.84 \pm 0.24 \mathrm{a}$ & $1.8 \pm 0.12$ & $* * *$ \\
\hline
\end{tabular}

$a, b, c$ Mean values with different superscripts in a row indicate statistically significant differences among agro-ecologies $(p<0.05)$

N: Number of Respondents; SEM: Standard Error of Means; SL: Level of Significance; NS: Non-Significant

\section{Species of livestock kept and reasons for keeping} livestock

Cattle are the dominant livestock species in all agro-ecologies. The higher proportion of cattle holding in all agro-ecologies could be due to high demand of oxen for cultivation and other farm activities. In the mid altitude there was the highest number of cattle than low and high altitudes because of easy access to veterinary services and feed resources. Significantly higher number of sheeps per $\mathrm{HH}$ in mid altitude than low altitude and goats holding were significantly higher in low altitude than high altitude, due to the presence of larger area of browsing land in low altitude and natural pasture in mid altitude. Number of horses and mules kept per household were significantly higher in high and mid than low altitudes because of suitability of highlands for horse and mule rearing with lower incidences of diseases and larger natural pasture as compared to low altitudes.

\section{Seasonality of feed resource availability (\%)}

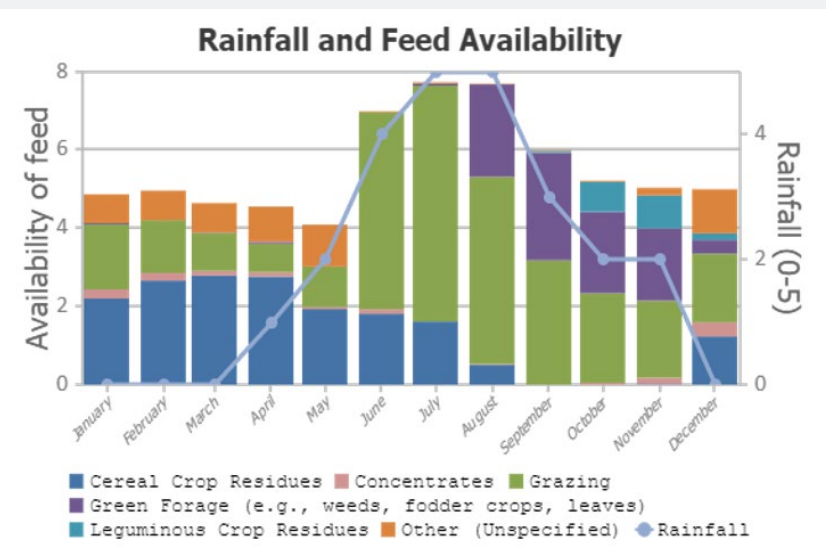

Figure 1: Composition of livestock feed throughout the year in relation to rainfall pattern in mid altitude agro-ecology.

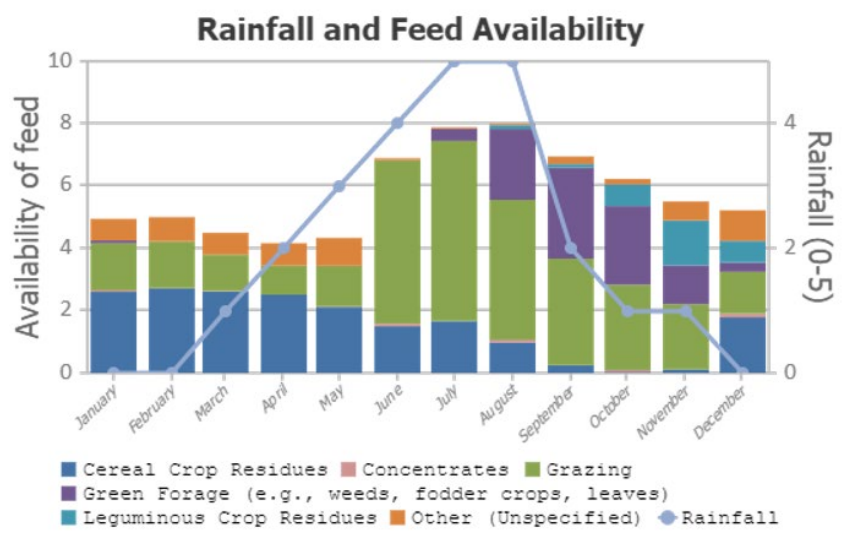

Figure 2: Composition of livestock feed throughout the year in relation to rainfall pattern in low altitude agro-ecology. 


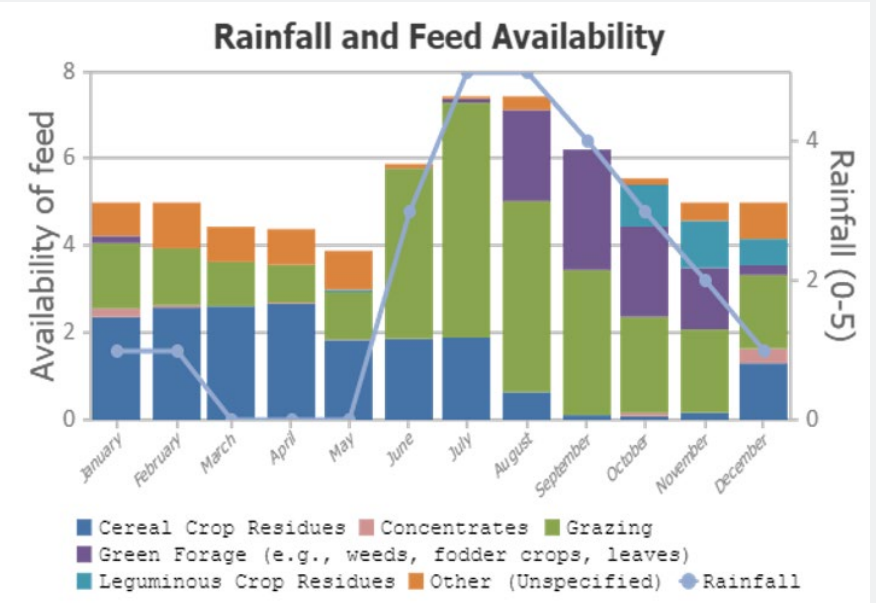

Figure 3: Composition of livestock feed throughout the year in relation to rainfall pattern in high altitude agro-ecology.

Figure $1 \& 2$ and Figure 3 show composition of feedstuffs throughout the year in relation to rainfall pattern in mid, low and high altitudes, respectively. availability of natural pasture and crop residues is governed by seasons of the year and rainfall patterns which are nearly similar across agro-ecologies. There are variations in availability of feed resources in terms of quantity and type of feeds. Natural pasture is major feed resource in wet season. Crop residues and stubble grazing were reported to be the major feed resources during the dry season. The availability of natural pasture is positively correlated with rainfall pattern and was increased from June to October but declined as the dry season approaches whereas crop residues are more abundant immediately following crop harvest from January to May (Figure 1-3). This pattern of feed fluctuation in availability was similar in the three agro-ecologies. Most of the natural pasture was available to livestock during the rainy season and declined towards crop harvesting period. Overall feed biomass availability was high from June to October and was the least from April to May in all agroecologies (Figure 1-3). Purchased feeds, conserved feeds and nonconventional feeds were used to copeup with feed shortage.

The study indicated that livestock feed accessibility and type vary according to seasons of the year which is consistent with earlier reports $[27,28,14]$. Natural pasture is reported to be the major feed sources in wet season, and crop residues and stubble grazing during the dry season $[29,30,11]$ which agree with the findings of this study. Feed is in good supply from June to October, as there is better growth of pasture, weeds and crop thinning which reconcile with earlier reports $[27,31,32]$. Purchased feeds, conserved feeds and non-conventional feeds were used to cope the livestock feed shortage during critical periods which is similar with previous reports $[33,30,27]$.

\section{Major constraints of livestock production}

The results of the focus group discussions, key informant interview and field observations revealed that feed shortage in terms of quantity and quality, limited knowledge, poor genetic potential of indigenous animals, disease and land shortage were the main constraints affecting livestock production in all agroecologies in decreasing order of importance (Table 2) and is in line with results reported in studies conducted in developing countries [10,34-41]. The following reports support the findings in this study. Feed shortage, livestock diseases, low productivity, water scarcity and predators in descending order of importance were earlier identified as major constraints [42]. Shortage of grazing land, diseases and parasites, inadequate veterinary service and low milk production potential of indigenous cattle were the major constraints of livestock production [41]. Similarly, lack of quality animal feed, diseases, lack of improved breed, shortage of land, lack of awareness on improved forage production and shortage of forage seeds/cuttings were major constraints in decreasing order of importance [43].

Table 2: Pair wise ranking of major challenges facing livestock production.

\begin{tabular}{|c|c|c|c|c|c|c|c|c|}
\hline \multirow{3}{*}{ Identified Problems } & \multicolumn{6}{|c|}{ Agro-Ecology } & \multirow{2}{*}{\multicolumn{2}{|c|}{ Overall }} \\
\hline & \multicolumn{2}{|c|}{ High Altitude } & \multicolumn{2}{|c|}{ Mid Altitude } & \multicolumn{2}{|c|}{ Low Altitude } & & \\
\hline & Score & Rank & Score & Rank & Score & Rank & Score & Rank \\
\hline Livestock feed shortage & 4 & 1 & 3 & 2 & 4 & 1 & 3.66 & 1 \\
\hline Limited knowledge/awareness & 3 & 2 & 4 & 1 & 3 & 2 & 3.33 & 2 \\
\hline Poor genetic make-up of animals & 2 & 3 & 3 & 2 & 2 & 3 & 2.33 & 3 \\
\hline Diseases & 0 & 5 & 1 & 4 & 1 & 4 & 0.66 & 4 \\
\hline Land shortage & 1 & 4 & 0 & 5 & 0 & 5 & 0.33 & 5 \\
\hline
\end{tabular}


In addition, feed shortage, lack of initial capital, disease, market and labour (herder) were among the reported constraints [44]. Likewise, feed shortage, disease prevalence mainly bovine trypanosomiasis, lack of initial capital, water and labor scarcity were identified as major livestock production constraints in decreasing order of importance [45]. Moreover, feed shortage, water scarcity, disease and low productivity of animals were assessed to be the major livestock production constraints [46]. Furthermore, feed shortage was found out to be the major and most important constraint of livestock production $[27,37,42,44,47]$.

\section{Contribution of feed resources}

Dry matter contribution of available feed resources: The dry matter (DM) contribution of feed resources to livestock diets in all agro-ecologies is shown in Table 3. Crop residues contributed the largest portion of feed DM. Natural pasture and cut and carry were the second largest contributors of DM to the total diet. In high altitude, about $73 \%$ of the DM of livestock feed is obtained from crop residues, natural pasture and cultivated fodder while purchased feeds and cut and carry accounted for the remainder. Similarly, in low altitude, the largest share of livestock feed DM $(78 \%)$ is obtained from crop residues and natural pasture. Natural pasture and crop residues contributed $77 \%$ of DM of the total diet in mid altitude (Table 3).

Differences in DM contribution of crop residues, cultivated fodder, cut and carry and purchased feeds among agro-ecologies were significant $(\mathrm{p}<0.05)$. However, DM contribution of natural pasture was not significantly different among agro-ecologies. The DM contribution of the crop residues were higher $(\mathrm{p}<0.01)$ in low and mid altitudes than high altitude. The DM contribution of cut and carry was higher $(\mathrm{p}<0.01)$ in mid altitude than high and low altitudes. The DM contribution of cultivated fodder $(p<0.001)$ and purchased feeds $(\mathrm{p}<0.01)$ was higher in high altitude than mid and low altitudes (Table 3).

Table 3: Mean dietary DM, ME and CP contribution (\%, Mean \pm SEM) of available feed resources in sampled $\mathrm{HH}$.

\begin{tabular}{|c|c|c|c|c|c|}
\hline \multirow{2}{*}{ Feed Resources } & \multicolumn{3}{|c|}{ Agro-Ecology } & \multirow{2}{*}{ Overall $(\mathrm{N}=90)$} & \multirow{2}{*}{ SL } \\
\hline & High Altitude ( $\mathrm{N}=18)$ & Low Altitude $(\mathrm{N}=18)$ & Mid Altitude (N=54) & & \\
\hline \multicolumn{6}{|c|}{ Dry Matter (DM) Contribution (\%) } \\
\hline Crop residues & $28.2 \pm 2.06 \mathrm{a}$ & $55.67 \pm 2.06 \mathrm{~b}$ & $54.23 \pm 1.19 \mathrm{~b}$ & $46.03 \pm 1.05$ & ** \\
\hline Natural pasture & $24.20 \pm 1.21$ & $22.27 \pm 1.21$ & $22.94 \pm 0.64$ & $23.14 \pm .56$ & Ns \\
\hline Cut and carry & $15.75 \pm 0.76 \mathrm{ab}$ & $13.32 \pm 0.76 a$ & $17.18 \pm 0.44 \mathrm{~b}$ & $15.41 \pm .39$ & ** \\
\hline Cultivated fodder & $20.63 \pm 1.84 \mathrm{c}$ & $1.3 \pm 1.84 \mathrm{a}$ & $3.15 \pm 1.06 \mathrm{~b}$ & $8.36 \pm .94$ & *** \\
\hline Purchased feeds & $11.22 \pm 1.48 \mathrm{c}$ & $7.45 \pm 1.48 \mathrm{ab}$ & $2.46 \pm 0.85 \mathrm{a}$ & $7.04 \pm .75$ & ** \\
\hline \multicolumn{6}{|c|}{ Metabolisable Energy ( MJ ME/kg) Contribution (\%) } \\
\hline Crop residues & $31.67 \pm 1.23 \mathrm{a}$ & $52.91 \pm 1.23 \mathrm{~b}$ & $51.12 \pm 0.71 \mathrm{~b}$ & $45.23 \pm .63$ & $* * *$ \\
\hline Natural pasture & $23.79 \pm 0.96 \mathrm{ab}$ & $23.49 \pm 0.96 \mathrm{a}$ & $23.65 \pm 0.55 \mathrm{a}$ & $23.64 \pm .49$ & NS \\
\hline Cut and carry & $17.16 \pm 0.62 \mathrm{ab}$ & $15.61 \pm 0.62 \mathrm{a}$ & $19.69 \pm 0.36 \mathrm{~b}$ & $17.49 \pm .32$ & ** \\
\hline Cultivated fodder & $15.83 \pm 0.69 \mathrm{c}$ & $1.22 \pm 0.69 \mathrm{a}$ & $3.39 \pm 0.39 \mathrm{~b}$ & $6.81 \pm .35$ & *** \\
\hline Purchased feeds & $11.55 \pm 0.88 \mathrm{c}$ & $6.78 \pm 0.88 \mathrm{~b}$ & $2.15 \pm 0.46 \mathrm{a}$ & $6.83 \pm .41$ & $* * *$ \\
\hline \multicolumn{6}{|c|}{ Crude Protein (CP) Contribution (\%) } \\
\hline Crop residues & $28.47 \pm 3.03 a$ & $49.75 \pm 3.03 c$ & $42.33 \pm 1.75 b$ & $40.19 \pm 1.54$ & *** \\
\hline Natural pasture & $23.96 \pm 1.06 \mathrm{a}$ & $26.56 \pm 1.06 \mathrm{~b}$ & $27.96 \pm 0.61 b$ & $26.16 \pm .54$ & $*$ \\
\hline Cut and carry & $15.53 \pm 0.58 \mathrm{a}$ & $15.88 \pm 0.58 \mathrm{a}$ & $20.95 \pm 0.34 \mathrm{~b}$ & $17.45 \pm 0.29$ & *** \\
\hline Cultivated fodder & $21.26 \pm 0.3 c$ & $2.89 \pm 0.3 \mathrm{a}$ & $6.33 \pm 1.73 b$ & $10.16 \pm 1.53$ & $* * *$ \\
\hline Purchased feeds & $10.78 \pm 0.75 \mathrm{c}$ & $4.93 \pm 0.75 b$ & $2.44 \pm 0.43 a$ & $6.05 \pm .38$ & $* * *$ \\
\hline
\end{tabular}

$a, b, c$ Mean values with different superscripts in a row indicate statistically significant difference between agro-ecologies $(p<0.05)$

SEM: Standard Error of Means; SL: Level of Significance; NS: Non-Significant.

Crop residues contributed the largest portion of feed DM during the dry season which agrees with earlier report [9]. The DM contribution reported for crop residues in the current study agrees with earlier reports $[48,49]$. On the other hand, the DM contribution of crop residues in the current study was greater $[1,6,14,32,50,51]$, but lower than earlier reports $[11,31,52]$. These differences might be due to differences in variety of crops grown and soil fertility of the areas.
The contribution of natural pasture to livestock feeds is generally declining due to expansion of crop farming [48]. The DM contribution of natural pasture in the current study was comparable $[10,14,32]$, higher $[52,53]$, but lower than those earlier reported $[1,6,31,50,51]$. This might be due to differences in environmental condition, size of natural pasture and forage species/botanical composition in the natural pasture. Cut and carry has become important feed sources due to shortage of grazing lands [48]. The DM contribution of cut and carry was 
comparable $[40,41]$; higher $[41,48,54]$, but less than those earlier reported $[14,49,42]$. This might have been caused by differences in soil fertility and forage species and crops grown.

The contribution of cultivated fodder as livestock feed is comparatively small in all agro-ecologies. The DM contribution of cultivated fodder in the present study was comparable with previous findings $[6,10,43]$. On the other hand, the DM contribution of cultivated fodder in the present study area was higher than results earlier reported $[1,14,33]$. However, the finding in the current study was less than those reported earlier [42,53]. This might have been due to differences in variety of cultivated forages. The DM contribution of purchased feeds in the present study was comparable with the previous results reported $[6,41,49]$, but it was higher $[1,14]$, and lower than those earlier reported $[44,53]$. These differences might be due to differences in DM content of purchased feeds.

Metabolisable energy contribution of available feed resources: Metabolisable energy (ME) contribution of feed resources to livestock diets in all agro-ecologies is shown in Table 3. Crop residues contributed the largest proportion of ME. Natural pasture and cut and carry were the second largest contributor for ME of the total diet. In high altitude, majority of the ME of livestock feed is obtained from crop residues; natural pasture and cut and carry while purchased feeds and cultivated fodder accounted for the rest. In a similar way, in low altitude, the largest share of livestock feed is obtained from natural pasture and crop residues, which accounted for $76 \%$ of ME of the diet. In analogous way, natural pasture and crop residues contributed to the largest proportions of ME of the total diet in mid altitude (Table 3).

The ME contribution of crop residues, cultivated fodder, cut and carry and purchased feeds were different $(\mathrm{p}<0.05)$ among agro-ecologies. However, ME contribution of natural pasture is not significantly different among agro-ecologies. The ME contribution of crop residues was higher $(\mathrm{p}<0.001)$ in low and mid altitudes than high altitude. The ME contribution of cut and carry were higher $(\mathrm{p}<0.01)$ in mid altitude than high and low altitudes. The ME contribution of cultivated fodder and purchased feeds were higher $(\mathrm{p}<0.001)$ in high altitude than mid and low altitudes (Table 3).

Crop residues contributed the largest portion of feed ME during the dry season. However, its contribution to overall dietary ME was quite low probably because of poor quality of crop residues due to delay at harvest and poor storages [9]. The ME contribution reported for crop residues in the current study were similar to previous result reported [45], but were higher [14,49], and lower than those results earlier reported [31]. This might be due to variations in variety of crops, amount of rainfall and soil fertility of the areas.

The ME contribution of natural pasture was comparable with the preceding results reported [31,42], however it was greater [53], but lower than [14,39-41], those reported for Arbaminch Zuria, Bonke, Mirab Abaya, Arbegona, Bonazuria and Bensa district (39.7\%, 28.1\%, 35.4\%, 37.4\%, 30.0\%, 35\%, respectively). This might be a reflection of differences in environment and forage species found in the natural pastures. The ME contribution of cut and carry was comparable with previous results $[40,46,47]$, but higher [52,41], and lower [14,35,42,45], than those reported earlier. These differences might have been caused by variations in soil fertility, forage species and environment. The ME contribution of cultivated fodder in the present study was comparable with previous findings reported $[41,48,49]$, but it was greater than those earlier reported by $[14,40,45]$; however, it was lower than other reports $[39,42,49]$, possibly due to differences in cultivated forage varieties and forage management.

The ME contribution of purchased feeds to livestock feed was very low in all agro-ecologies studied which is in agreement with a previous report [7]. The ME contribution of purchased feeds in the present study was comparable with previous reports $[41,40,49]$, but was higher $[14,45,48]$, and lower $[35,39,55]$, than other reports. High cost and limited vailability of agro-idustrial byproducts and lack of awareness could be reasons for differences in use of purchased feeds.

Crude protein contribution of available feed resources: The crude protein (CP) contribution of feed resources to livestock diets in all agro-ecologies is shown in Table 3. Crop residues contributed the largest proportion of feed CP. Natural pasture and cut and carry were the second largest contributors of CP of the total diet. In high altitude, largest proportions of CP of the total diet were supplied by crop residues, natural pasture and cut and carry; while in low altitude, it was crop residues and natural pasture. Natural pasture and crop residues contributed the largest proportions of dietary CP in mid altitude (Table 3).

Differences in CP contribution of crop residues, natural pasture, cultivated fodder, cut and carry and purchased feed among agro-ecologies were significant $(\mathrm{p}<0.05)$. The CP contribution of crop residues were higher $(\mathrm{p}<0.001)$ in low altitude than mid and high altitudes. The CP contribution of natural pasture were higher $(p<0.05)$ in mid and low altitude than high altitude. The CP contribution of cultivated fodder and purchased feeds was higher $(\mathrm{p}<0.001)$ in high altitude than mid and low altitudes. The CP contribution of cut and carry was higher $(\mathrm{p}<0.001)$ in mid altitude than high and low altitudes (Table 3).

Protein is major limiting nutrient in feeding ruminant [51]. Crop residues contributed the largest portion of feed $\mathrm{CP}$ in the study area. However, its contribution to overall dietary CP was quite low probably because of poor quality of the crop residues due to delay at harvest and poor storage [9]. The CP contribution reported for crop residues in the current study was similar $[35,45]$, but higher $[14,39,41,42]$, and lower than [31], those earlier reported. These variations might be due to differences in variety of crops, cultural practices and soil fertility of the areas. The CP contribution of natural pasture was comparable with previous reports $[14,31,52]$, but higher $[35,39,42,45]$, and lower $[40,41,47]$ than those of other reports. These variations could 
possibly be due to difference in environment and forage species found in the pasture. The CP contribution of cut and carry in this study was comparable with previous results reported [40,41,47] but higher $[39,50]$ lower $[14,35,42,45]$ than earlier reports. These differences might have been caused by variation in soil fertility, forage species and environment [56-59].

The CP contribution of cultivated fodder in the present study was comparable with previous findings $[41,47,49]$; it was higher than those reported earlier $[14,35,45]$, but less than other reports $[39,42,44,49]$. These variations might be due to differences in variety of cultivated forage. The CP contribution of purchased feeds in the present study was comparable with previous results reported $[35,40,41]$ ssss, and is higher than other reports $[14,42,45,46]$, but lower than those reported by other authors $[15,39,49]$. These differences might have been caused by variation in availability of such feeds and lack of awareness quality of feeds of livestock holders.

Intervention options: The following were found to be possible intervention options to mitigate shortage of feed in the study area in order of importance.

a. Adequate training and follow-up on existing crop residues management, improvement and utilization.

b. Training on improved forage development and utilization.

c. Improve management and utilization of communal and private grazing lands.

d. Provide supplemental feeds.

e. Mixing improved/processed available feeds with legume and concentrate supplementation.

f. Training on feeding management, feed conservation and utilization of conserved feeds.

g. Grazing land management and improvement.

h. Production of improved cultivated fodder varieties.

\section{Conclusion and recommendation}

Crop residues, crop aftermath and natural pasture were the major feed resources. Crop residues contributed largest proportion of feed DM, ME and CP in low, mid and high altitudes. Highest crude protein (CP) contribution was from crop residues in low (49.75 \pm 3.03$)$ and mid altitudes $(42.33 \pm 1.75)$ than in high altitude $(28.47 \pm 3.03)$ and lowest was from purchased feeds with corresponding CP contribution in high $(10.78 \pm 0.75)$, mid $(2.44 \pm 0.43)$ and low altitudes $(4.93 \pm 0.75)$. Highest enery (ME) contribution was from crop residues in low $(52.91 \pm 1.23)$ and mid altitudes $(51.12 \pm 0.71)$ than in high altitude $(31.67 \pm 1.23)$ and lowest was found from purchased feeds with ME contribution in high (11.55 \pm 0.88$)$, mid $(2.15 \pm 0.46)$ and low altitudes $(6.78 \pm 0.88)$ and from that of cultivated fodder in high $(15.83 \pm 0.69$.), mid $(3.39 \pm 0.39)$ and low altitudes $(1.22 \pm 0.69)$. These major feed resources found in the district are of low nutritional quality. Thus, chemical and biological treatments of them; supplementing them with concentrates and training farmers on grazing management, proper collection, conservation and utilization of available feed resources would improve their nutritional value.

\section{References}

1. CSA (2017) Agricultural sample survey. Report on livestock and livestock characteristics (private peasant holdings). Central Statistical Agency (CSA): Addis Ababa, Ethiopia, p: 194.

2. Gelayenew B, Nurfeta A, Assefa G, Asebe G (2016) Assessment of livestock feed resources in the farming systems of mixed and shifting cultivation, Gambella regional state, south western Ethiopia. Global Journal of Science Frontier Research 16(5): 11-20.

3. Ulfina G, Habtamu A, Jiregna D, Chala M (2013) Utilization of brewer's waste as replacement for maize in the ration of calves. Web Pub J Agric Res 1(1): 8-11.

4. Kebede G, Assefa G, Feyissa F, Mengistu A (2016) A Review on some management and improvement practices of natural pasture in the Mid and High-altitude areas of Ethiopia. Int J Livest Res 6(5): 1-14.

5. Nigus A (2017) Pasture management and improvement strategies in Ethiopia. Journal of Biology, Agriculture and Healthcare 7(1): 69-78.

6. FAO. 2017. Africa sustainable livestock 2050-technical meeting and regional launch, Addis Ababa, Ethiopia, 21-23 February 2017. FAO Animal Production and Health Report.No.12. Rome, Italy, p: 36.

7. Tolera A, Yami A, Alemu D (2012) Livestock feed resources in Ethiopia, challenges, opportunities and the need for transformation. Ethiopian animal feed industry Association, Addis Ababa, p: 132.

8. Gurmessa K, Tolemariam T, Tolera A, Beyene F, Demeke S (2015) Feed resources and livestock production situation in the Highland and Mid altitude areas of Horro and Guduru district of Oromia regional state, western Ethiopia. Sci Technol Arts Res J 4(3): 111-116.

9. Gurmessa K, Tolemariam T, Tolera A, Beyene F (2016) Production and utilization of crop residues in Horro and Guduru districts, western Ethiopia. Food Science and Quality Management, 48: 77-84.

10. Demeke S, Mekuriaw Y, Asmare B (2017) Assessment of livestock production system and feed balance in the watersheds of North Achefer district, Ethiopia. Journal of Agriculture and Environment for International Development 111(1): 175-190.

11. Gashe A, Zewdu T, Kassa A (2017) Feed resources in Gozamen district, East Gojjam zone, Amhara region. J Environ Anal Toxicol 7(2): 1-12.

12. Africa RISING. 2014. Africa Research in Sustainable Intensification for the Next Generation, Ethiopian Highlands Project Technical report, p: 14.

13. Chalchissa G, Mekasha Y, Urge M (2014) Feed resources quality and feeding practices in urban and peri-urban dairy production system of southern Ethiopia. Tropical and subtropical agro-ecosystems 17(3): 539-546.

14. Gizaw S, Ebro A, Tesfaye Y, Mekuriaw Z, Mekasha Y, et al. (2017) Feed resources in the highlands of Ethiopia: A value chain assessment and intervention options. International Livestock Research Institute (ILRI), Nairobi, Kenya. p. 50.

15. Yami M, Begna B, Teklewold T (2013) Enhancing the productivity feeding strategies and utilization. Int J Livestock Production 1: 15-29.

16. CSA (2013) Agricultural sample survey. Report on livestock and livestock characteristics (private peasant holdings). Central Statistical Agency (CSA): Addis Ababa, Ethiopia. p: 194.

17. IPMS (2014) Burie Pilot Learning Site Diagnosis and Program Design. p: $91 . v$

18. BZDOA (2017) Unpublished office report. Burie Zuria district Of Agriculture, Ethiopia, p. 3. 


\section{Agricultural Research \& Technology: Open Access Journal}

19. Arsham H (2007) Questionnaire design and survey sampling. SySurvey: The Online Survey Tool

20. ILCA (1990) Livestock systems research manual. No.12, section 1.Working document. ILCA. Addis Ababa, Ethiopia, p: 8.

21. Dereje G, Eshetu A (2011) Agro-ecologies of Ethiopia and major crops grown; Collaboration with EIAR, p: 12.

22. ILRI (2015a) Feed Assessment Tool (FEAST) focus group discussion guide. ILRI Editorial and Publishing Services, p: 27.

23. ILRI (2015b) Feed Assessment Tool (FEAST) individual farmer interview questionnaire. Nairobi: ILRI, p: 21.

24. Duncan A, York L, Lukuyu B, Samaddar A, Stur W (2012) Feed Assessment Tool (FEAST). Dzowela, (Eds.). Animal feed resources for small-scale livestock producers. Proceedings, p. 21

25. ILRI. 2015c. Feed Assessment Tool (FEAST) Data Application User Manual. Nairobi: ILRI, p: 55.

26. SPSS (2011) Statistical Package for Social Science Inc. Chicago, Illinois, USA. Version 20.

27. Debela M, Animut G, Eshetu M (2017) Assessment of feed resources availability and utilization in DaroLabu district, western Hararge zone, Ethiopia. Journal of Natural Sciences Research 7(13): 50-57.

28. Emana MM, Ashenafi M, Getahun A (2017) Opportunity and constraints of livestock feed resources in Abol and Lare districts of Gambella region, Ethiopia. Nutri Food SciInt J 3(4): 1-9.

29. Assefa F, Tigistu T, Lambebo A (2015) Assessment of the production systems, major constraints and opportunities of sheep production in Doyogena district, KembataTambaro zone, southern Ethiopia. Journal of Biology, Agriculture and Healthcare 5(21): 37-41.

30. Lemma, M., Negesse, T. and Nurfet, A. 2016. Assessment of feed resource availability and quality in Kedida Gamela district, southern Ethiopia. International Journal of Environment, Agriculture and Biotechnology, 1(1): 31-39.

31. Gashaw M, Defar G (2017) Livestock feed resources, nutritional value and their implication on animal productivity in mixed farming system in Gasera and Ginnir districts, Bale zone, Ethiopia. Int J Livest Prod 8(2): 12-23.

32. Geremew G, Negesse T, Abebe A (2017) Assessment of availability and nutritive values of feed resources and their contribution to livestock nutrient requirements in Chire district, southern Ethiopia. Agri Res and Tech: Open Access J 7(4): 1-5.

33. Duguma B, Janssens GPJ (2016) Assessment of feed resources, feeding practices and coping strategies to feed scarcity by smallholder dairy producers in Jimma town, Ethiopia. Springer Plus 5(1): 1-10.

34. Wondatir Z, Damtew E (2015) Assessment of livestock production system and feed resources availability in Hawassa Zuria district, Ethiopia. International Livestock Research Institute (ILRI), Nairobi, Kenya, p: 21.

35. Mekasha A, Gerardd B, Tesfaye K, Nigatub L, Duncan JA (2014) Interconnection between land use/land cover changes and herders'/ farmers' livestock feed resource management strategies: a case study from three Ethiopian eco-environments. Agriculture Ecosystems and Environment 188: 150-162.

36. Berhanu T, Abebe G, Thingtham J, Tusdri S, Prasanpanich S (2017) Availability of feed resources for goats in pastoral and agro-pastoral districts of South Omo zone, Ethiopia. International Journal of Research Granthaalayah 5(3): 154-160.

37. Biratu K, Haile S (2017) Assessment of livestock feed availability, conservation mechanism and utilization practices in South Western Ethiopia. Acad Res J Agri Sci Res 5(7): 461-470.

38. Husen, M., Kechero, Y. and Molla, M (2016) Availability, yield and utilization practices of livestock feed resources in Gilgel Gibe
Catchments of Jimma zone, south western Ethiopia. Global Veterinaria 17(1): 78-94.

39. Mekasha Y, Biazen B, Tegegne A, Shewage T, Zewdie T, et al. (2015) Spatio-temporal dynamics of natural grazing lands and livestock holding in Sidama highlands of southern Ethiopia: Implications for sustainable grazing land development. Journal of Agricultural Engineering and Biotechnology, 3(3): 109-119.

40. Amole AT, Ayantunde AA (2016) Assessment of existing and potential feed resources for improving livestock productivity in Niger. Int J Agric Res 11(2): 40-55.

41. Beriso K, Tamir B, Feyera T (2015) Characterization of smallholder cattle milk production system in Aleta Chukko district, southern Ethiopia. J Adv Dairy Res., 3(1): 1-8.

42. Umutoni C, Ayantunde A, Sawadogo JG (2015) Evaluation of feed resources in mixed crop-livestock systems in Sudano-Sahelian zone of Mali in west Africa. International Journal of Livestock Research 5(8): 27-36.

43. Wondatir Z (2015) Assessment of livestock production system and feed resources availability at Melka watershed of Nile Basin, Jeldu district, western Ethiopia. Global Journal of Science Frontier Research, 15(9): 7-20.

44. Abera M, Tolera A, Assefa G (2014) Feed resource assessment and utilization in Baresa watershed, Ethiopia. International Journal of Science and Research 3(2): 66-72.

45. Worku Z, Tilahun S, Tolemariam T, Jimma W (2016) Assessment of prevailing cattle fattening practices in Jimma zone, south western Ethiopia. Global Veterinarian 17(2): 105-113.

46. Altaye ZS, Kassa B, Agza B, Alemu F, Muleta G (2014) Smallholder cattle production systems in Metekel zone, north west Ethiopia. Research Journal of Agriculture and Environmental Management 2(3): 151-157.

47. Assefa D, Nurfeta A, Banerjee S (2013) Assessment of feed resource availability and livestock production constraints in selected kebele of AdamiTulluJiddo Kombolcha district, Ethiopia. Afr J Agric Res 8(29): 4067-4073.

48. Hailemariam S, Mohamed A, Silassie GM, Gebeyew K (2017) Identification and nutritional characterization of major sheep and goats feed resource in Jigjiga zone, Ethiopia Somali regional state. World Applied Sciences Journa, 35(3): 459-464.

49. Negesse T, Adugna G, Ajebu N (2016) Assessment of livestock feed resource and effect of supplementing sweet potato vine hay on growth performance and feed intake of grazing local goats in Aleta Chuko district, Sidama zone SNNPRS, Ethiopia. International Journal of Environment, Agriculture and Biotechnology 1(3): 466-475.

50. Wondatir Z, Adie A, Duncan AJ (2015b) Assessment of livestock production and feed resources at Kerekicho, Angacha district, Ethiopia. International Livestock Research Institute (ILRI), Nairobi, Kenya, p: 21.

51. Kashongwe BO, Mwangi WL, Bebe OB, Matofari WJ, Huelsebusch C (2017) Influence of on-farm feed formulations and hygiene interventions on milk yield and quality in smallholder dairy farms in Kenya. Int J Agr Ext 5(2): 11-17.

52. Muyekho FN, Siamba D, Agevi H, Etiang SA (2014) Characterization of the livestock production system and potential to enhance productivity through improved feeding in Sabatia, Vihiga Country, Kenya. International Livestock Research Institute (ILRI), Nairobi, Kenya, p: 16

53. Wondatir Z, Adie A, Duncan AJ (2015a) Assessment of livestock production and feed resources at Robit-Bata, Bahir Dar, Ethiopia. International Livestock Research Institute (ILRI), Nairobi, Kenya, p: 22.

54. Duressa D, Kenea D, Keba W, Desta Z, Berki G, et al. (2014) Assessment of livestock production system and feed resources availability in three villages of Diga district, Ethiopia. International Livestock Research Institute (ILRI), Nairobi, Kenya, p: 27. 
55. Umutoni C, Ayantunde AA (2014) Evaluation of feed resources in mixed crop-livestock production systems in the Sudano-Sahelian zone of Mali. International Livestock Research Institute (ILRI), Nairobi, Kenya, p: 26.

56. Deresse A, Assefa T, Wondatir Z, Seifu T, Negassa J, et al. (2014) Assessment of livestock production system and feed resources availability at Melka watershed, Jeldu district, Ethiopia. International Livestock Research Institute (ILRI), Nairobi, Kenya, p: 21

57. Olaniyi JB, Anandan S, Adedayo OS, Augustine AA, Iheanacho O, et al. (2014) Characterization of the farming and livestock production systems using the feed assessment tool (FEAST) in selected local government areas of Oyo state, Nigeria. International Livestock Research Institute, Nairobi, Kenya, p: 26.
58. Tefera G, Tegegne F, Mekuriaw Y, Melaku S, Tsunekawa A (2015) Effects of different forms of white lupin (Lupinus albus) grain supplementation on feed intake, digestibility, growth performance and carcass characteristics of Washera sheep fed rhodes grass (Chloris gayana) hay-based diets. Trop Anim Health Prod 47(8): 81-90.

59. Francis NM, Donald S, Humphrey A, Sebastian AE (2014) Characterization of the livestock production systems and the potential to enhance productivity through improved feeding in Sabatia, Vihiga country, Kenya, p: 15.

\begin{tabular}{l} 
Your next submission with Juniper Publishers \\
will reach you the below assets \\
- Quality Editorial service \\
- Swift Peer Review \\
- Reprints availability \\
- E-prints Service \\
- Manuscript Podcast for convenient understanding \\
- Global attainment for your research \\
- Manuscript accessibility in different formats \\
( Pdf, E-pub, Full Text, Audio) \\
- Unceasing customer service \\
Track the below URL for one-step submission \\
https://juniperpublishers.com/online-submission.php \\
\hline
\end{tabular}

